\title{
22. GEOTECHNICAL ENGINEERING CHARACTERIZATION OF HYDRAULICALLY PISTON-CORED DEEP OCEAN SEDIMENTS ${ }^{1}$
}

\author{
William H. Walton, Chas. T. Main, Inc., Boston Massachusetts \\ Dwight A. Sangrey, Carnegie-Mellon University, Pittsburgh, Pennsylvania \\ and \\ Scott A. Miller, Department of Civil Engineering, Carnegie-Mellon University, \\ Pittsburgh, Pennsylvania
}

\begin{abstract}
The hydraulic piston coring device (HPC-15) allows recovery of deep ocean sediments with minimal disturbance. The device was used during Leg 72 of the Deep Sea Drilling Project (DSDP) aboard the Glomar Challenger. Core samples were recovered from bore holes in the Rio Grande Rise in the southwest Atlantic Ocean. Relatively undisturbed sediment cores were obtained from Holes $515 \mathrm{~A}, 516,517$, and 518 . The results of shipboard physical property measurements and on-shore geotechnical laboratory tests on these cores are presented in this chapter.

A limited number of $0.3 \mathrm{~m}$ cores were obtained and used in a series of geotechnical tests, including one-dimensional consolidation, direct shear, Atterburg limit, particle size analysis, and specific gravity tests. Throughout the testing program, attention was focused on assessment of sample disturbance associated with the HPC-15 coring device.

The HPC-15 device limits sample disturbance reasonably well in terrigenous muds (clays). However, sample disturbance associated with coring calcareous sediments (nannofossil-foraminifer oozes) is severe. The noncohesive, granular behavior of the calcareous sediments is vulnerable to severe disturbance, because of the design of the sampling head on the device at the time of Leg 72 .

A number of modifications to the sampling head design are recommended and discussed in this chapter. The modifications will improve sample quality for testing purposes and provide longer unbroken core samples by reducing friction between the sediment column and the sampling tool.
\end{abstract}

\section{INTRODUCTION}

Until recently, the Deep Sea Drilling Project (DSDP) was equipped to recover only rotary core samples from the upper $200 \mathrm{~m}$ of an ocean sediment profile. This technique produced some disturbance in recovered core samples (Demars and Nacci, 1978). A number of studies have addressed physical property measurements of these relatively disturbed samples, including Boyce (1974), Hamilton (1976), Bennett and Keller (1973), and Demars and Nacci (1978).

The development of the hydraulic piston coring device (HPC-15) has brought the opportunity to recover relatively undisturbed core samples. Since late 1978, the HPC-15 device has permitted recovery of continuous, undisturbed samples from sediment profiles exceeding sub-bottom depths of $50 \mathrm{~m}$. This device has provided specimens for sedimentologists, paleontologists, and physical properties specialists to examine uniformly continuous sediment profiles with moderate compression of the sediment fabric. The compression is attributed to the effects of advancing the tool into the sediment column.

Both laboratory and shipboard geotechnical testing can be used to evaluate the relative disturbance of sediment cores obtained from the HPC-15 device. Schmertman (1955) and Silva (1974) discussed the influence of

\footnotetext{
${ }^{1}$ Barker, P. F., Carlson, R. L., Johnson, D. A., et al., Init. Repts. DSDP, 72: Washington (U.S. Govt. Printing Office).
}

sample disturbance on the behavior of the one-dimensional consolidation tests.

Use of HPC-15 in the sampling program of Leg 72 provided sediment for assessing the effectiveness of this tool in reducing sample disturbance. Results of this evaluation, along with recommendations for redesign of HPC-15, are contained in this chapter.

\section{HPC PROCESS, HANDLING, AND LABORATORY PROGRAM}

To obtain high quality sediment cores, DSDP engineers designed and implemented the hydraulic piston coring HPC-15 device (see Fig. 1). The HPC-15 has been in operation since December 1978, Leg 64. Cores are taken by injecting a $4.4 \mathrm{~m}$ ( $15 \mathrm{ft}$.) long sampling tube by hydraulic pressure into the sediment at a high velocity, and then withdrawing the sample with a wire line through the drill string to the ship's deck. The HPC-15 recovers relatively undisturbed $63.5 \mathrm{~mm}$ diameter core. By repetitive coring downward in the same hole, relatively undisturbed continuous cores are recovered. The HPC-15 system was designed with limits for total penetration below the seafloor of $200 \mathrm{~m}$. Maximum shear strength of recovered material is $188.1 \mathrm{kN} / \mathrm{m}^{2}(1.92 \mathrm{~kg} /$ $\mathrm{cm}^{2}$ ) as reported by Storms (1979). Coring is severely limited when the shear strength consistently exceeds $98.0 \mathrm{kN} / \mathrm{m}^{2}\left(1.00 \mathrm{~kg} / \mathrm{cm}^{2}\right)$. The design of the sampling head restricts full penetration when stiffer sediments are encountered.

Once the core barrel reaches the ship's deck, the core liner filled with sediment is removed from the core bar- 

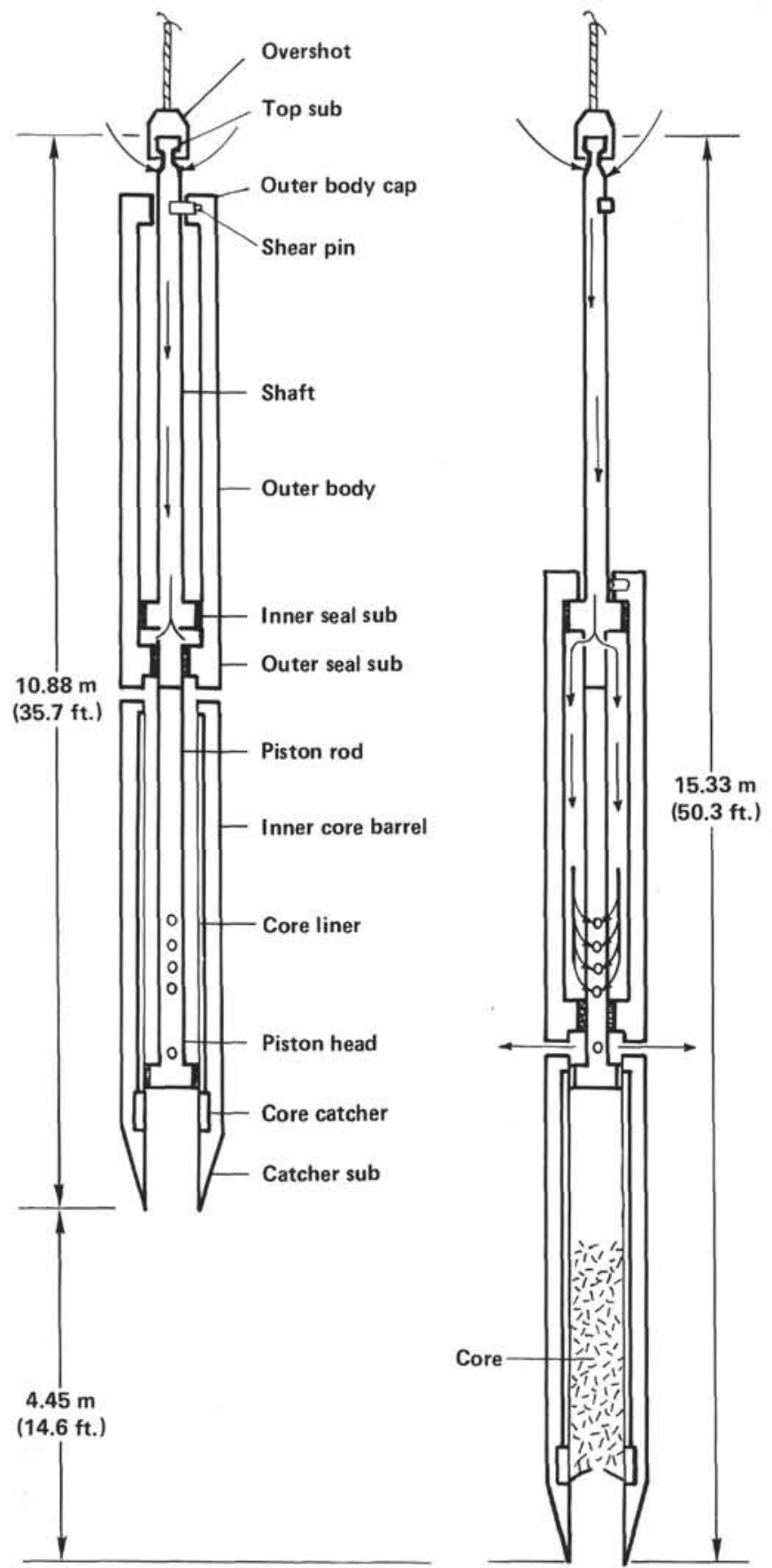

Figure 1. Hydraulic piston coring device (HPC-15).

rel. Each core is then cut into $1.5 \mathrm{~m}$ sections starting from the bottom. Short specimens ( 30 to $35 \mathrm{~cm}$ long) are immediately removed from these sections as needed by the physical properties staff and refrigerated in an upright position to preserve sediment fabric for shore-based geotechnical analyses. The special cores from Leg 72 were then transported to Carnegie-Mellon University (CMU), Pittsburgh, Pennsylvania. These cores were refrigerated, to simulate ambient seafloor temperatures and retard biological degradation.

The special short sections of core presented many problems, the major one being that small amounts of sediment physically limited the total amount of geotech- nical testing which could be done on each of the cores. Careful planning eliminated the possibility of wasting cores. Sample trimmings were saved, and these trimmings were used for tests requiring disturbed samples. These tests include particle size analysis, specific gravity, and Atterburg limits. Undisturbed samples were used for one-dimensional consolidation and direct shear testing. A core-cutting device was specially designed and built to open the polycarbonate core liner with a minimum of disturbance to the core. Two end platens were machined such that the core liner would fit into the end platens. The core liner was then secured between the end platens using a metal lathe. Once the core liner was fitted into the lathe, the core liner was cut away. The core itself was cut using a wiresaw. The cut section was then removed and the core extruded for testing.

Physical property test methods have been specified for most soil and marine sediment testing. For this program, the procedures described by the American Society for Testing and Materials (ASTM) and Lambe (1951) were used. For a complete list of tests conducted and applicable ASTM standards, see Table 1.

\section{LABORATORY MEASUREMENTS}

Laboratory consolidation, direct shear, and other physical properties tests were performed on short specimens (approximately $30 \mathrm{~cm}$ ) taken at Holes 515A, 516, 517 , and 518. The test results are limited, but they provide information on the effects of sampling disturbance (swelling and remolding) on the physical properties measurements. Laboratory investigations provide an advantage over shipboard testing by controlling the state of stress and the void ratio, thereby providing a baseline for comparing data on swollen and disturbed samples obtained on board (Demars and Nacci, 1978).

Physical properties information obtained on board and in the laboratory is given in Table 2 . The sample from Hole $515 \mathrm{~A}$ is a high plasticity terrigenous clay. Wet unit weights from the trimmed laboratory test specimen $\left(1.63 \mathrm{Mg} / \mathrm{m}^{3}\right)$ were slightly less than the on-board measurement $\left(1.68 \mathrm{Mg} / \mathrm{m}^{3}\right)$. Samples obtained from Holes 516,517 , and 518 were nannofossil-foraminifer sands, with low to moderate plasticity. Wet unit weights from trimmed laboratory test specimens varied from 1.60 to $1.81 \mathrm{Mg} / \mathrm{m}^{3}$ and agree well with shipboard measurements determined using the $1 \mathrm{~cm}^{3}$ syringe method.

\section{CONSOLIDATION TESTS}

To determine consolidation-compressional characteristics and assess sampling disturbance, a laboratory oedometer was used to perform one-dimensional com-

Table 1. Sediment laboratory testing methods.

\begin{tabular}{lcc}
\hline \multicolumn{1}{c}{ Laboratory test } & $\begin{array}{c}\text { Number of tests } \\
\text { per sample core }\end{array}$ & $\begin{array}{c}\text { ASTM reference } \\
\text { number }\end{array}$ \\
\hline Liquid limit & 1 & D423 \\
Plastic limit and plasticity index & 1 & D424 \\
Particle size analysis & 1 & D422 \\
Specific gravity & 1 & D854 \\
One-dimensional consolidation & 1 & D4235 \\
Direct shear & 1 & D3080 \\
\hline
\end{tabular}


Table 2. Summary of sediment physical properties.

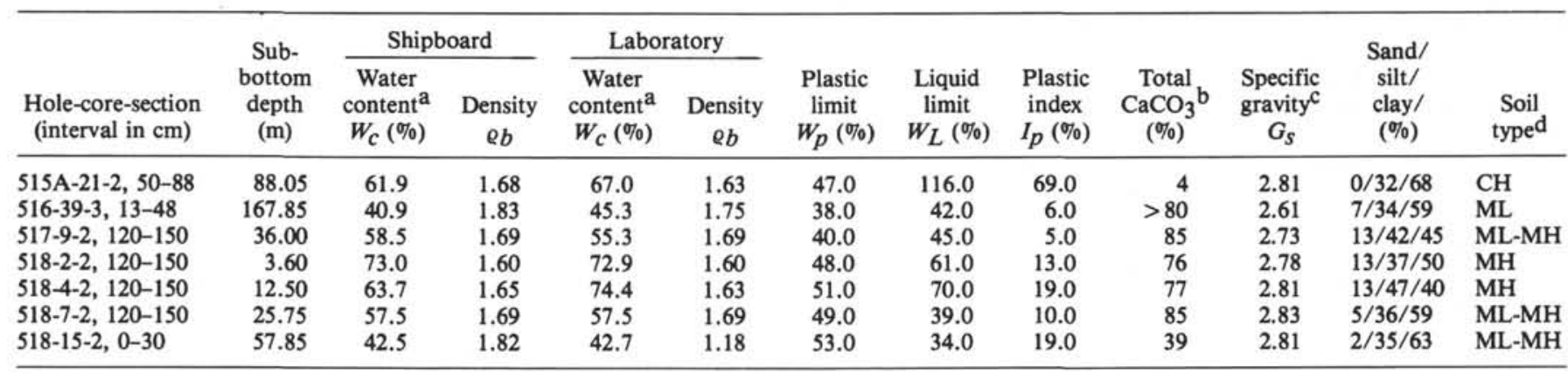

${ }^{a} W_{c}=$ Weight of water/weight of solids.

b Shipboard results of carbonate bomb tests.

c Grain density.

d Unified soil classification system.

pression tests on the deep-sea sediments. Compression is the process of volume change under variations in effective stress. Measurements of compression are important because they indicate the depth to which a structure, or any load, can sink into a sediment (Buchan et al., 1967). Also, the consolidation-compression test yields information on the stress history of the sample in terms of the entire sediment body. Overburden stress, density, porosity, and water content can be examined using this method.

The consolidation-compression tests were performed in an oedometer in which the sample was loaded axially while contained within a rigid ring between two porous plates. Increasing loads were applied to the sample at regular intervals, and the rate of consolidation at each load increment was observed and recorded.

Five consolidation-compression tests were performed. The results were plotted as void ratio, $e$, versus the logarithm of effective overburden stress, $\sigma_{v}^{\prime}$. Each loading was allowed to remain on the sample well past primary consolidation (negligible excess pore fluid pressure), at which time the next load was added (each successive load was double the preceding one). This involved increasing loads of typically $25,50,100,200,400,800$, 1600 , and $3200 \mathrm{kN} / \mathrm{m}^{2}$. The samples were unloaded and then reloaded. Consolidation samples subjected to repeated cycles of loading and unloading will have a unique $e$ - $\log \sigma_{v}^{\prime}$ curve (Casagrande [1936], Schmertman [1955], Terzaghi and Peck [1967]). This curve is composed of three sections: (1) a relatively horizontal portion of the loading curve up to a marked change in the slope; (2) a relatively straight portion after the change in slope and with increasing load; and (3) an unloading section.

Figures 2 and 3 illustrate $e$ - $\log \sigma_{v}^{\prime}$ consolidation curves for each of the five tests. The curves show the estimated in situ overburden stress $\left(\sigma_{v_{0}}^{\prime}\right)$ and the preconsolidation stress $\left(\sigma_{p}^{\prime}\right)$, constructed by the Casagrande (1936) technique. The slope of the virgin loading curve (section 2) or the compression index $\left(C_{c}\right)$, and the unloading curve (section 3 ) or rebound index $\left(C_{r}\right)$, are also shown. All of the compression data are listed in Table 3.

Theoretically, the overburden stress $\left(\sigma_{v_{o}}^{\prime}\right)$ and preconsolidation stress $\left(\sigma_{p}^{\prime}\right)$ should be identical for nor- mally consolidated sediments. Sample disturbance in retrieval, or in sample preparation in the laboratory, will change this agreement. Consolidation tests indicate agreement between $\sigma_{v_{o}}^{\prime}$ and $\sigma_{p}^{\prime}$ for the terrigenous clays; however, the calcareous sediments are overconsolidated $\left(\sigma_{p}^{\prime}>\sigma_{v_{o}}^{\prime}\right)$. If the preconsolidation stress is greater than the vertical overburden stress, the sediment is considered to be cemented or overconsolidated. Cementation within the nannofossil-foraminifer sands may result from diagenesis.

The maximum point of curvature was difficult to define for the test results from this laboratory program using the Casagrande technique. No definitive break in the $e$-log $\sigma_{v}^{\prime}$ curve indicates the correct location of the preconsolidation pressure. This behavior is typical of remolded samples (Schmertman, 1955). Remolding tends to obliterate stress history and aging effects (bonding) and provides slightly lower compression indices than in undisturbed samples (Demars and Nacci, 1978).

The $e-\log \sigma_{v}^{\prime}$ curve can be used to quantify the degree of sample disturbance resulting from sampling and handling procedures. A less-disturbed sample will show a sharper curvature in the vicinity of the preconsolidation stress than samples which have considerable structural (fabric) disturbance. Compression data from highly remolded samples will show little resemblance to data from undisturbed samples (Silva, 1974). Using the $e-\log \sigma_{v}^{\prime}$ construction techniques developed by Schmertman (1955), Silva (1974) developed a simpler method of quantifying the degree of disturbance. This method defines a disturbance index $\left(I_{D}\right)$ as follows:

$$
I_{D}=\frac{\Delta e}{\Delta \mathrm{e}_{\mathrm{o}}},
$$

where $\Delta e=$ change in void ratio for sample obtained and $\Delta e_{o}=$ change in void ratio for disturbed sample.

Figure 4 illustrates the simplified method of determining the degree of disturbance in the terrigenous clay sample. Table 3 shows that $I_{D}$, for all samples tested, ranges from 0.45 to 0.69 - which, according to Silva (1974), indicates that the samples tested range between "moderate" and "considerable" disturbance. 


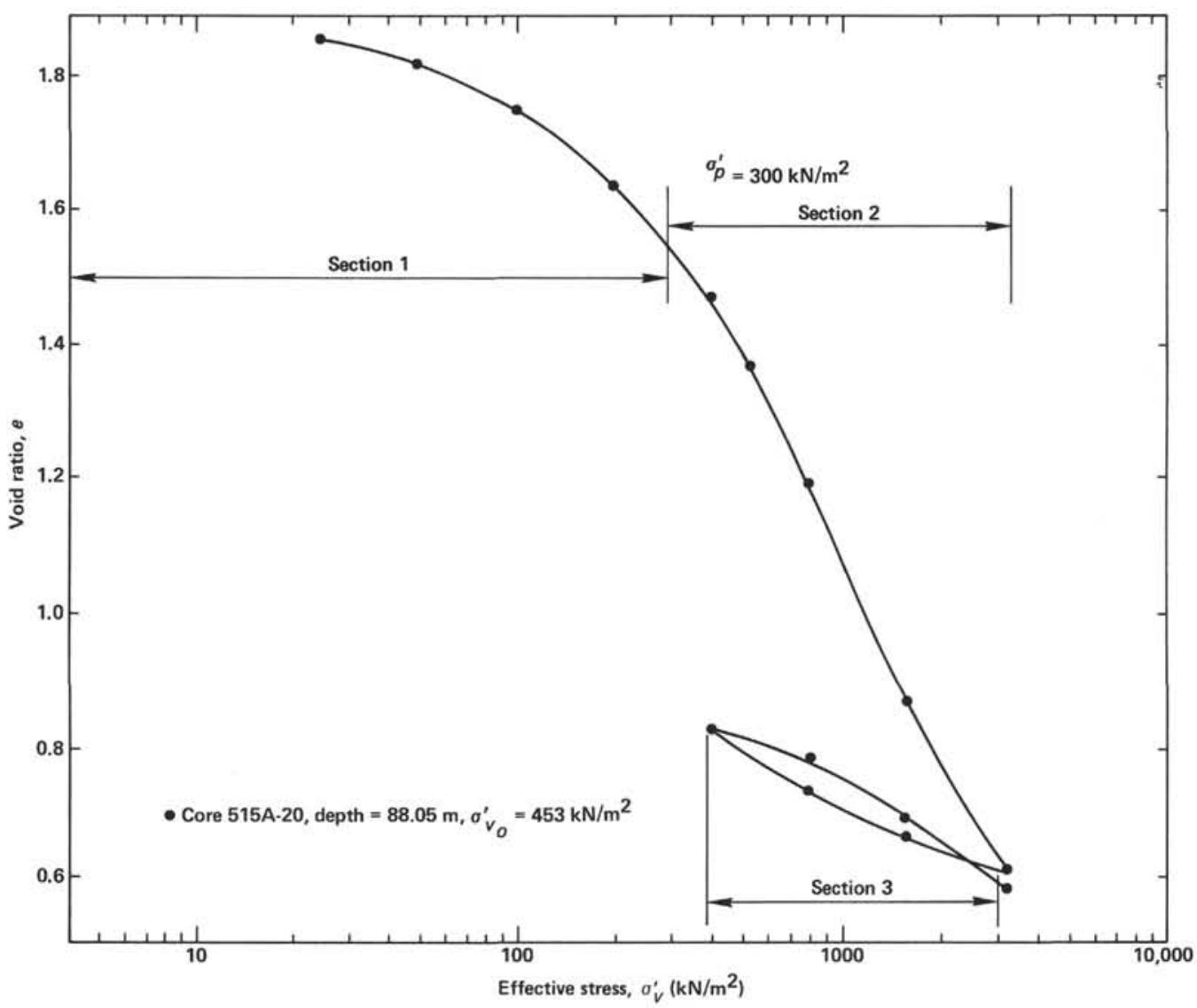

Figure 2. Consolidation curve, Hole 515A. $\sigma_{\mathrm{Q}}^{\prime}$ is preconsolidation stress; $\sigma_{\mathrm{v}_{\mathrm{o}}^{\prime}}^{\prime}$ is in situ overburden stress.

In 1944, Skempton investigated the relationship between liquid limit $\left(w_{L}\right)$ and the compression index $\left(C_{c}\right)$ for remolded clays; it was found that values of $C_{c}$ for different clay increase consistently with increasing liquid limits. Upon testing a large number of remolded clays, Skempton proposed a relationship for $C_{c}^{\prime}$ :

$$
C_{c}^{\prime}=0.007\left(w_{L}-10\right),
$$

in which the liquid limit is expressed as a percentage. In 1967, Terzaghi and Peck extended Skempton's work by relating $C_{c}^{\prime}$ to $C_{c}$. For an ordinary clay of medium to low sensitivity, the value of $C_{c}$ corresponding to the field consolidation line appeared to be equal to $1.30 C_{c}^{\prime}$ :

$$
C_{c}=1.30 C_{c}^{\prime}=0.009\left(w_{L}-10\right) \text {. }
$$

A comparison between the laboratory $C_{c}$ and the empirically determined $C_{c}^{\prime}$ as shown in Table 2 is possible for the terrigenous clay sample. However, the nannofossil foraminifer sands do not match up as well. The laboratory $C_{c}$ is greater than the empirical value. The reason for this variation can be explained by Terzaghi and Peck (1967): The difference between the real values of $C_{c}$ and those determined by the empirical equation are about $\pm 30 \%$. In addition, the presence of foraminifer sands reduces sediment compressibility dramatically, thereby disqualifying the use of Skempton's equation.

\section{DIRECT SHEAR TESTS}

A Wykeham-Farrance Direct Shearbox Apparatus was used to conduct consolidated-drained shear tests on the deep-sea sediments. Measurements of shear strength are important because they enable a geotechnical engineer to predict the bearing capacity and slope stability of the sediments. These predictions are necessary for evaluating the safety of future offshore structures and the safety of offshore pipelines and transmission cables.

The direct shear tests were performed on samples remolded at a water content above the liquid limit. The remolded sample was placed in a double-drained shearbox, and an axial normal load was applied. The rate of consolidation was observed until primary consolidation was complete. Once primary consolidation was complete, the upper and lower halves of the shear box were split, and an increasing horizontal force was applied to the upper half of the split box. This causes a relative horizontal displacement of the two halves, which results in the specimen being sheared along the dividing plane of the shearbox. Testing rates were selected so that excess pore fluid pressures could dissipate and the drained strength could be assessed. Each test was continued until the peak, drained strength of the sediment had been clearly defined. The test was repeated at least three times with incrementally increased loads on a newly remolded sample until a failure envelope was defined by 


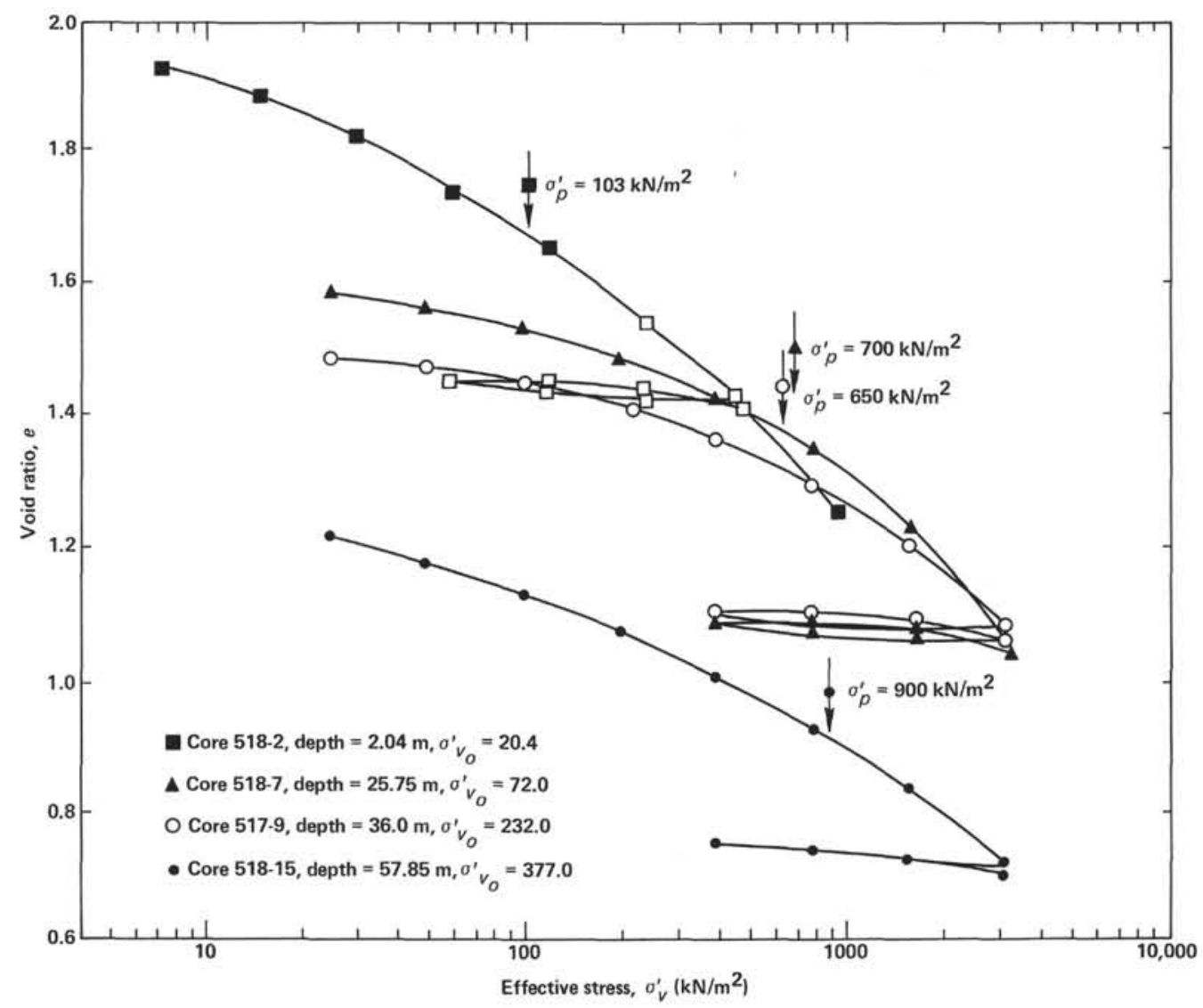

Figure 3. Consolidation curves, Holes 517 and 518. $\sigma_{\varrho}^{\prime}$ is preconsolidation stress; $\sigma_{v_{0}}^{\prime}$ is in situ overburden stress.

Table 3. Summary of sediment consolidation data.

\begin{tabular}{|c|c|c|c|c|c|c|c|c|c|c|}
\hline \multirow[b]{2}{*}{ Core } & \multirow{2}{*}{$\begin{array}{l}\text { Sub-bottom } \\
\text { depth } \\
\text { (m) }\end{array}$} & \multirow{2}{*}{$\begin{array}{c}\text { Water } \\
\text { content, } \\
W_{c}(\%)\end{array}$} & \multirow{2}{*}{$\begin{array}{l}\text { Initial } \\
\text { void } \\
\text { ratio, } e_{O}\end{array}$} & \multirow{2}{*}{$\begin{array}{c}\text { Initial } \\
\text { porosity, } \\
\phi\end{array}$} & \multicolumn{2}{|c|}{$\begin{array}{c}\text { Compression } \\
\text { index }\end{array}$} & \multirow{2}{*}{$\begin{array}{l}\text { Swell } \\
\text { index } \\
C_{r}\end{array}$} & \multirow{2}{*}{$\begin{array}{c}\text { Overburden } \\
\text { pressure, } \\
\sigma_{v_{o}}^{\prime}\left(\mathrm{kN} / \mathrm{m}^{2}\right)^{\mathrm{c}}\end{array}$} & \multirow{2}{*}{$\begin{array}{c}\text { Preconsolida- } \\
\text { tion } \\
\text { pressure } \\
\sigma_{p}^{\prime}\left(\mathrm{kN} / \mathrm{m}^{2}\right)^{\mathrm{d}}\end{array}$} & \multirow{2}{*}{$\begin{array}{c}\text { Disturbance } \\
\text { index } \\
I_{D}{ }^{e}\end{array}$} \\
\hline & & & & & $C_{c}$ & $C_{c}^{\mathrm{b}}$ & & & & \\
\hline 515A-21 & 88.05 & 67.0 & 1.92 & 0.66 & 1.00 & 0.95 & 0.23 & 453. & 300. & 0.46 \\
\hline $517-9$ & 36.00 & 55.3 & 1.54 & 0.61 & 0.38 & 0.32 & 0.02 & 232. & 650. & 0.45 \\
\hline $518-2$ & 2.04 & 72.9 & 2.04 & 0.67 & 0.53 & 0.46 & 0.02 & 20.4 & 103. & 0.56 \\
\hline $518-7$ & 25.75 & 57.5 & 1.69 & 0.63 & 0.55 & 0.35 & 0.02 & 72.0 & 700. & 0.53 \\
\hline $518-15$ & 57.85 & 42.7 & 1.26 & 0.56 & 0.44 & 0.39 & 0.03 & 377. & 900. & 0.69 \\
\hline
\end{tabular}

the shear strength data on a plot of shear stress, $\tau$, versus normal stress, $\sigma$. A failure envelope is defined in terms of its $y$-intercept and arc-tangent of the slope. Respectively, these are the effective cohesion, $c^{\prime}$, and the effective friction angle $\phi^{\prime}$. Table 4 gives the results of the direct shear test on each of the seven sediments. A range for both the friction angle and cohesion are given as the limits of the scatter in the data.

\section{SHIPBOARD MEASUREMENTS}

Continuous physical property testing was performed on sample cores obtained from the HPC-15 cored Holes $515 \mathrm{~A}, 516,517$, and 518. Shipboard testing consisted of examining retrieved cores from various depths for water content, wet-bulk density, porosity, and shear strength. These tests complement both the geologic interpretation of the sediment profile and additional shore-based geotechnical testing performed on limited core samples. Water content and specific gravity (grain density) measurements were made using the $1 \mathrm{~cm}^{3}$ syringe technique (Boyce, 1974). The $1 \mathrm{~cm}^{3}$ syringe was used to collect a measured volume of sediment for on-board analyses; however, Bennett and Keller (1973) noted that the volume was actually too small for accurate determinations of specific gravity and porosity. This sampling method is also dependent upon technique; occasionally the clays would crack and leave voids in the sampler as the tool was pushed into the core. This deformation leads to inaccuracies in calculating physical properties. Also, despite all precautions, some compression resulting from sampler head design occurs in almost all samples taken, leading to inaccurate volume measurements. 


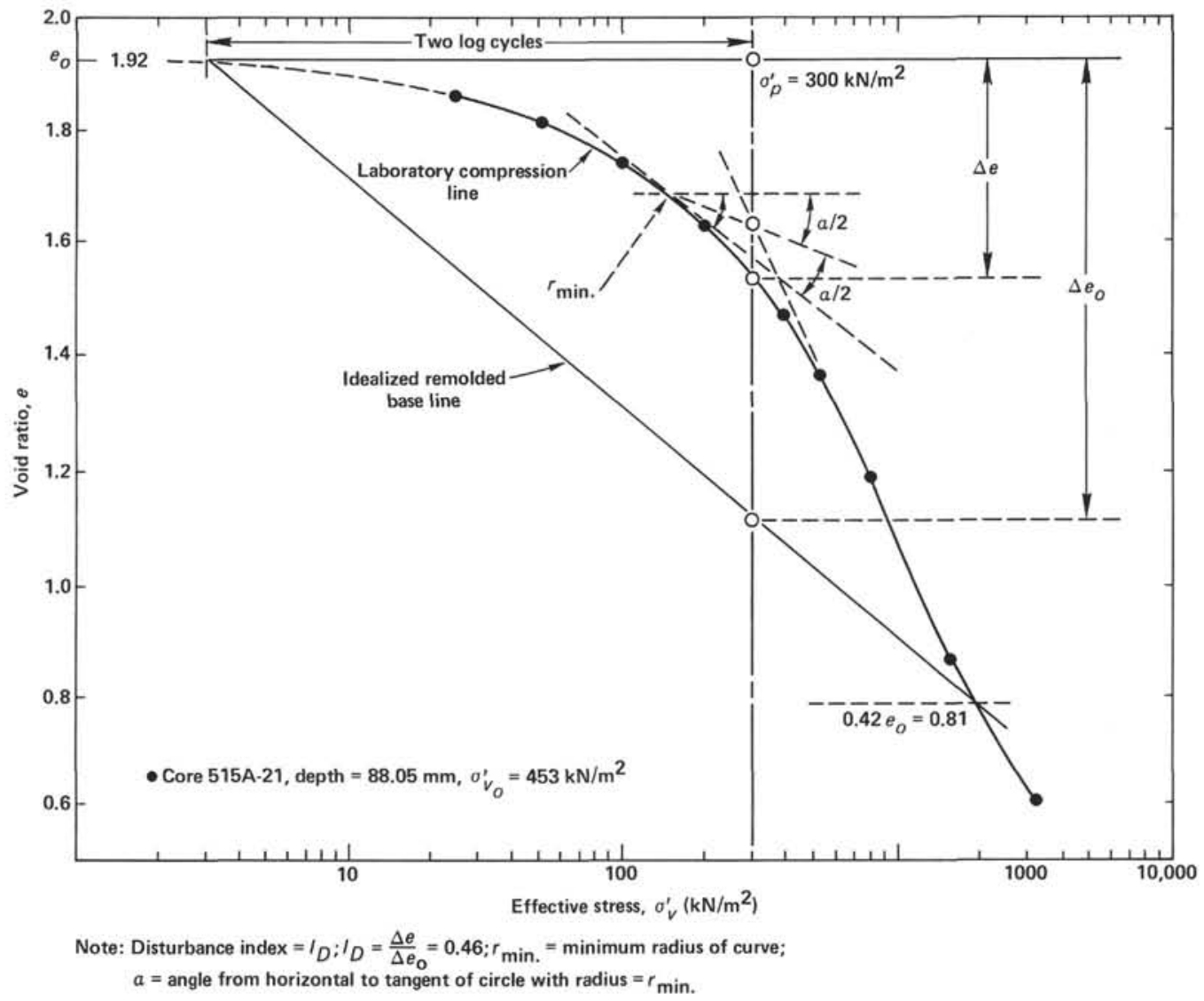

Figure 4. Disturbance index determination.

Table 4. Direct shear data.

\begin{tabular}{lcccl}
\hline & \multirow{3}{*}{$\begin{array}{c}\text { Sub-bottom } \\
\text { depth }\end{array}$} & & \multicolumn{2}{c}{ Laboratory data } \\
\cline { 5 - 6 } Core & $(\mathrm{m})$ & $W_{c}(\%)^{\mathrm{a}}$ & $\phi^{\prime}$ (degrees) & $\sigma_{v}^{\prime}\left(\mathrm{kN} / \mathrm{m}^{2}\right)$ \\
\hline $515 \mathrm{~A}-21$ & 88.05 & 67.0 & $14.67-23.62$ & $0-11.92$ \\
$516-39$ & 167.85 & 45.3 & $28.97-33.42$ & $0-9.64$ \\
$517-9$ & 36.00 & 55.3 & $28.06-33.7$ & $0-10.58$ \\
$518-2$ & 2.04 & 72.9 & $26.67-32.0$ & $0-11.62$ \\
$518-4$ & 12.50 & 74.4 & $29.31-31.8$ & $0-2.93$ \\
$518-7$ & 25.75 & 57.5 & $34.5-39.8$ & $0-10.10$ \\
$518-15$ & 57.85 & 47.7 & $23.71-28.81$ & $0-14.11$ \\
\hline
\end{tabular}

Note: $\phi^{\prime}$ is the effective friction angle; $\sigma_{v}^{\prime}$ is effective stress.

${ }^{a}$ Water content before testing.

The physical property results from Hole $515 \mathrm{~A}$ are presented in Figures 5, 6, and 7. A detailed analysis of the site lithology indicated that the sediment was a normally consolidated, uniformly continuous profile of highly plastic, grayish brown terrigenous clay with occasional nannofossil-rich layers and some foraminifer-rich layers. Increased sub-bottom depth was associated with decreased porosity and increased wet-bulk density. The water content generally decreased with depth, a trend expected with increasing overburden stress. In effect, the water was squeezed out from the sediment.

Shear strength results from Hole 515A are an excellent example of increased shearing resistance with depth in normally consolidated sediments. For purposes of comparison, three different shear strength measuring tools were used: the Wykeham-Farrance Vane Shear Device, the Soiltest CL-600 Torvane, and the Soiltest Pocket Penetrometer. Measurements by the three shear strength devices are highly correlated. Each test was performed at approximately regular intervals down-hole. Sample disturbance does not appear to be severe in the terrigenous clay cores.

The results from Hole 516 are presented in Figures 8 and 9. The principal components of the core were calcareous nannofossils and planktonic foraminifer oozes and sands. Total carbonates averaged $90 \%$ and exceeded $75 \%$ in all but 6 of over 350 carbonate bomb analyses (Site 516 chapter, this volume).

The HPC-15 cores from Hole 516 are disturbed. The water content and shear strength significantly changed within each $4.4 \mathrm{~m}$ core section. These variations are the result of the sandlike nature of the noncohesive and permeable nannofossil-foraminifer sands. This conclusion was deduced in part from the Torvane, wet-bulk density, and water content data. Water content generally decreases, and density and shear strength increase from the top of a core section to the bottom. Vibro-liquefaction within the HPC-15 core liner is a valid explanation for increased density and shear strength. The calcareous oozes and sands probably are remolded (disturbed) as the sediment intrudes further into the core liner. As the sediments liquefy, a sediment-water slurry passes to the top of the core tube. There were no significant variations 

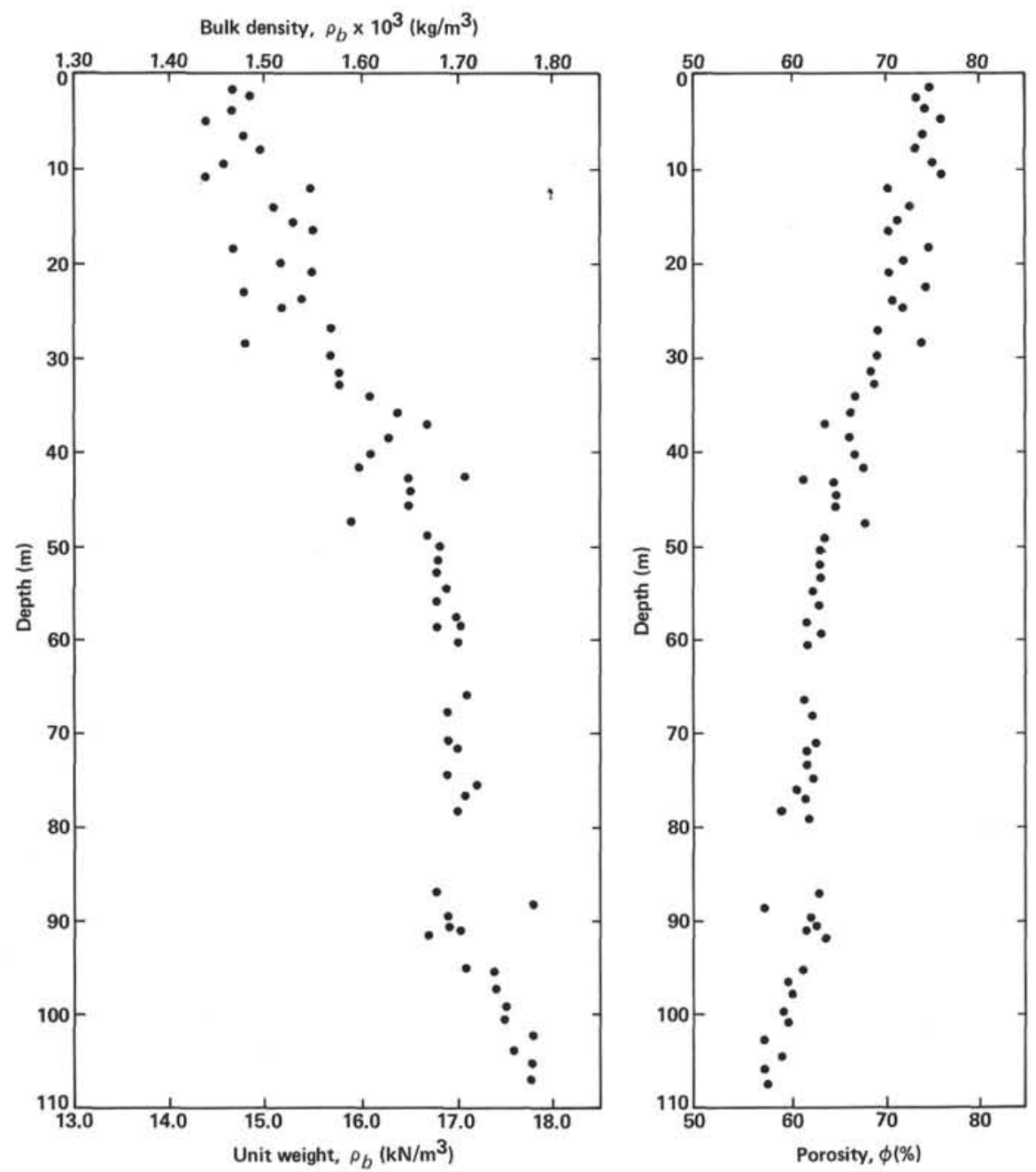

Figure 5. Unit weight and porosity data, Hole 515A.

in water content or shear strength over the length of a core section containing homogeneous, cohesive clay sediments (except for the top $50 \mathrm{~cm}$, which were loosened as a result of the previous wash boring) recovered in Hole 515A.

The entire sediment profile in Hole 516 is a mechanically disturbed nannofossil-foraminifer ooze and sand. The HPC-15 device caused immediate liquefaction (dewatering and remolding) of calcareous sediments. Additional disturbance occurred during sample retrieval and handling. It is safe, therefore, to conclude that the relatively uniform water content observed with increasing depth at Site 516 (the $w_{c}$ ranges from $58.7 \%$ at sub-bottom [ $0 \mathrm{~m}$ ] to $47.1 \%$ at $198.0 \mathrm{~m}$ ) was the result of sample redistribution and disturbance. The shear strength, wetbulk density, and porosity profiles (Figs. 8 and 9) should be viewed with caution.

A limited number of physical property tests were made on the twelve $4.4 \mathrm{~m}$ samples recovered from Hole 517. Tests included shear strength, water content, wet-bulk density, and porosity determinations. The sediment in Hole 517 (foraminifer-nannofossil ooze) was similar to that found in Hole 516. Excessive disturbance associated with HPC-15 coring of calcareous sediments may have caused variations in the physical properties. Based on earlier findings at Site 516, a decision was made to forgo extensive measurements on the disturbed cores.

Hole 518 comprises eighteen $4.4 \mathrm{~m}$ core sections. Test results are summarized in Figure 10. The deepest sediment recovered is from $71.9 \mathrm{~m}$ sub-bottom depth. The hole is divided into two lithologic units. The first unit (Cores 1 to 14) consists of foraminifer-nannofossil oozes and sands, and the second (Cores 15 through 18) is composed of terrigenous clays and marly nannofossil oozes. A number of physical properties measurements were made in Hole 518. The cohesive nature of these sediments made it quite suitable for HPC-15 sampling. The original fabric of the in situ sediment is better preserved in this HPC-15 hole, compared to Holes 516 and 517. Shear strength and wet-bulk density increase with depth. Water content and porosity decrease with depth-trends consistent with compaction and dewatering of sediment profiles.

To reiterate, the marked disturbance produced by the HPC-15 coring device in calcareous oozes is believed to have adversely affected the validity of measured physical properties as indicators of the in situ condition of sediments. Less sampling disturbance occurred in terrig- 


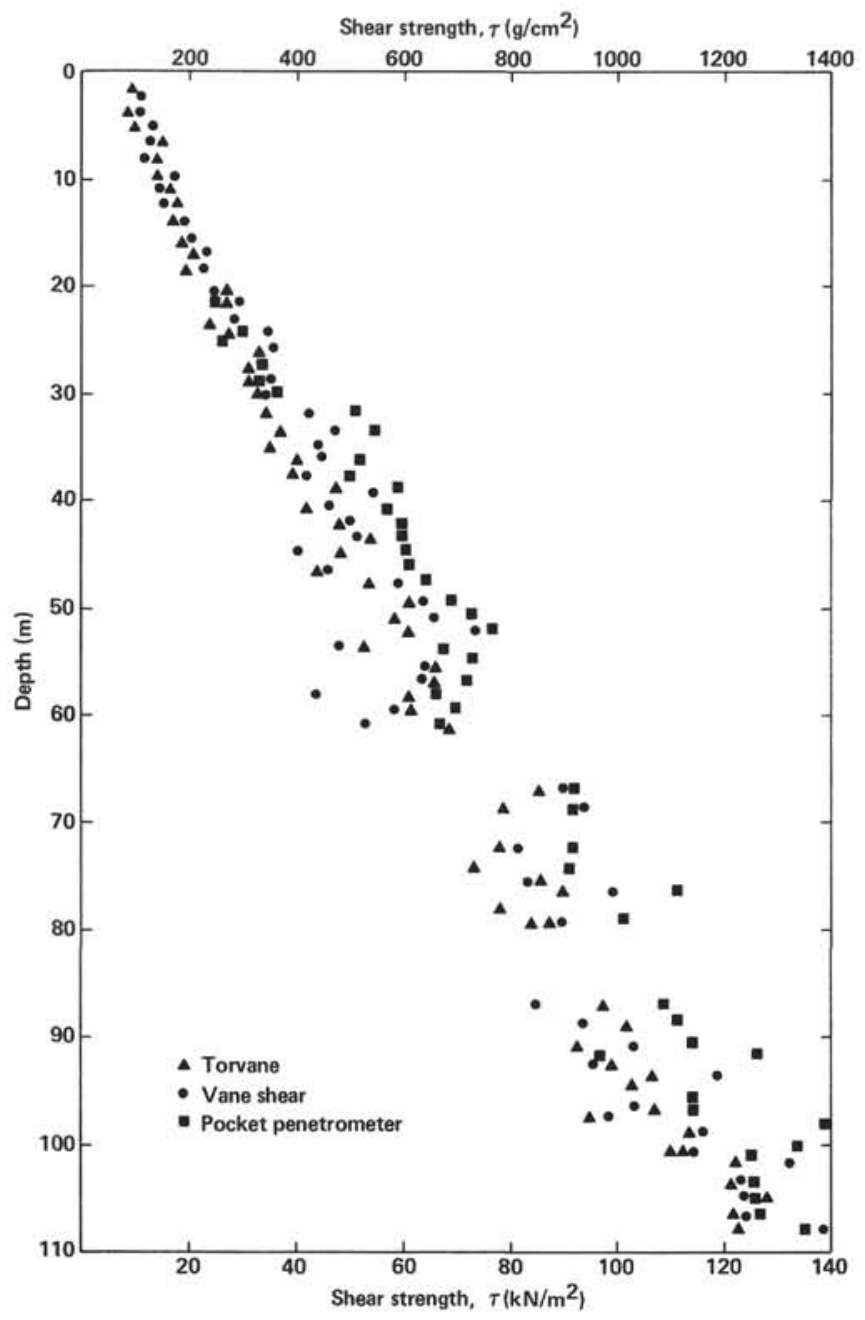

Figure 6. Shear strength data, Hole 515A.

enous clays, and the physical properties measured on these samples should be considered more representative.

\section{EVALUATION OF THE HPC DEVICE}

Leg 72 HPC cores were considerably disturbed by the HPC-15 device, specifically the noncohesive calcareous sediments cored in Holes 516, 517, and 518. Based on both shipboard and laboratory investigations, shipboard visual examination and shear strength, wet-bulk density, and water content measurements indicate that density and shear strength increase and water content decreases from the top of an individual HPC-15 core to the bottom.

Piston coring the coarse-grained sediment in Holes 516,517 , and 518 caused immediate liquefaction (dewatering and remolding). Additional sample disturbance occurred once the cores were brought on board. Rough handling and placement of the core liner on its side aggravated the situation. Therefore, it is reasonable to conclude that the uniform water contents of samples recovered from Hole 516 result from sediment fabric redistribution and sampling disturbance, and that the shear strength, wet-bulk density, porosity, and water content may have been severely altered. Samples brought on

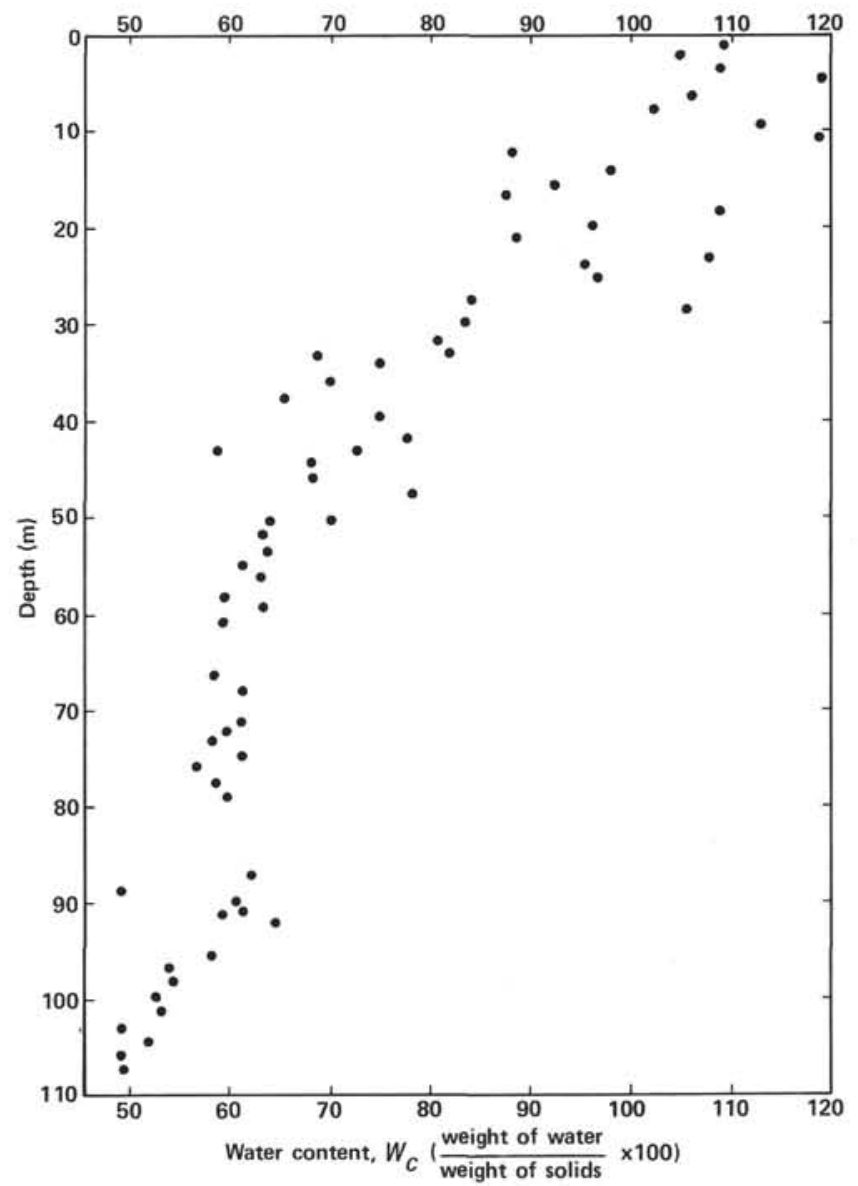

Figure 7. Water content data, Hole 515A.

board may have representative lithology, but they do not have the same physical properties that exist in situ. If, in the future, the DSDP requires reliable information concerning shearing resistance or stress-deformation characteristics of marine sediments, the degree of disturbance of the samples must be reduced to the minimum compatible with the benefits to be obtained. No matter how much the HPC device is modified, a certain amount of disturbance is inevitable.

For coring tools of a given diameter forced into the sediment in a continuous motion, the degree of disturbance depends on the area ratio,

$$
A_{r}(\%)=100\left(D_{e}^{2}-D_{i}^{2}\right) / D_{i}^{2},
$$

in which $D_{e}$ is the external diameter, and $D_{i}$ is the internal diameter of the samples (Rosfelder and Marshall, 1967). The area ratio of the currently used HPC- 15 device is $95 \%$; this value should not exceed approximately $20 \%$ if disturbance is to be minimized. Modifications of the existing HPC device could significantly improve coring results.

Figure 11 illustrates a modified HPC sampler head. The cutting shoe is far enough above the cutting edge to maintain a small area ratio. The sampler head has an expanded diameter to provide a larger open space for the remaining length of HPC core barrel to follow behind. 

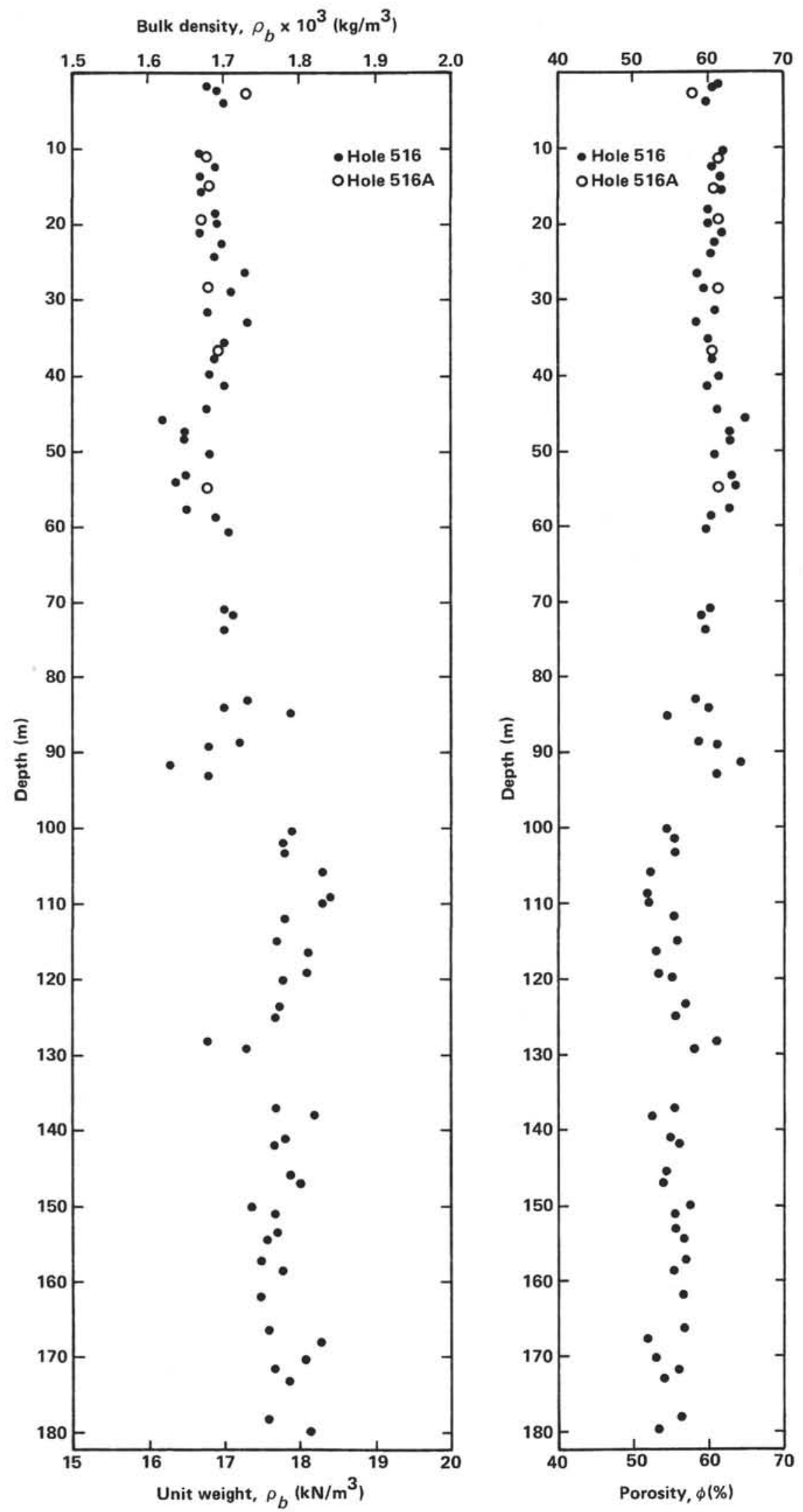

Figure 8. Unit weight and porosity data, Holes 516 and 516A. 

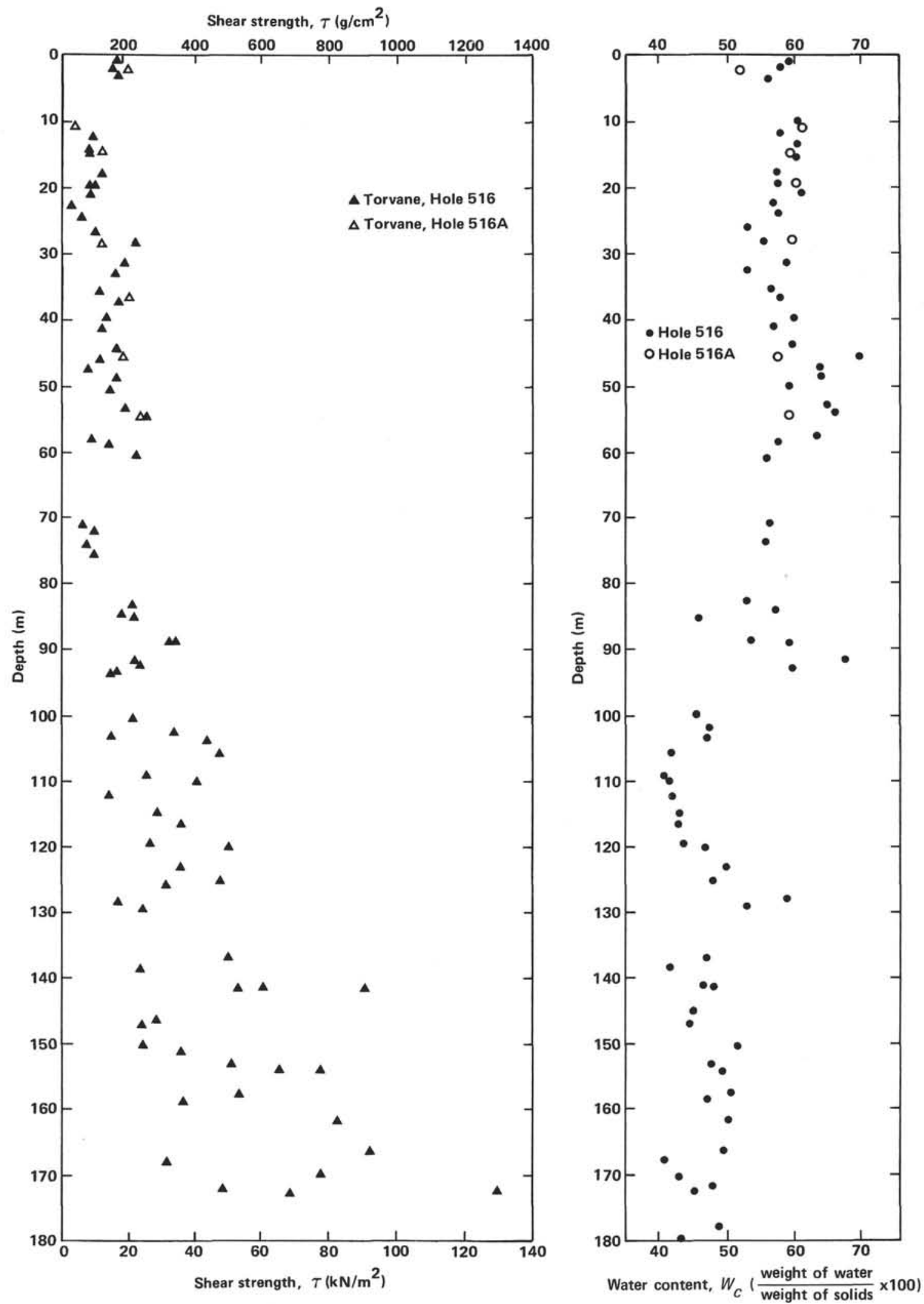

Figure 9. Shear strength and water content data, Holes 516 and 516A. 

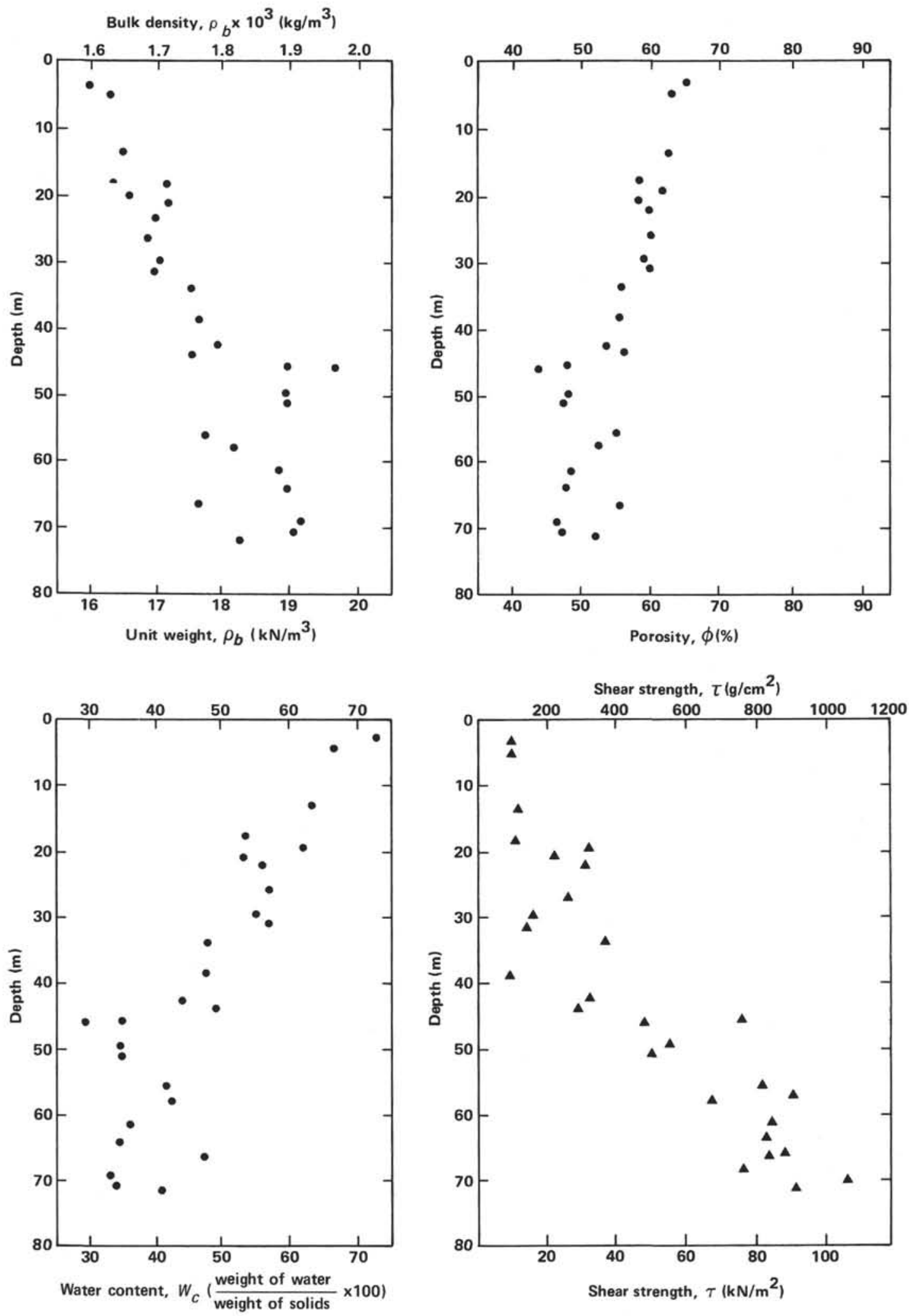

Figure 10. Physical properties, Hole 518. 


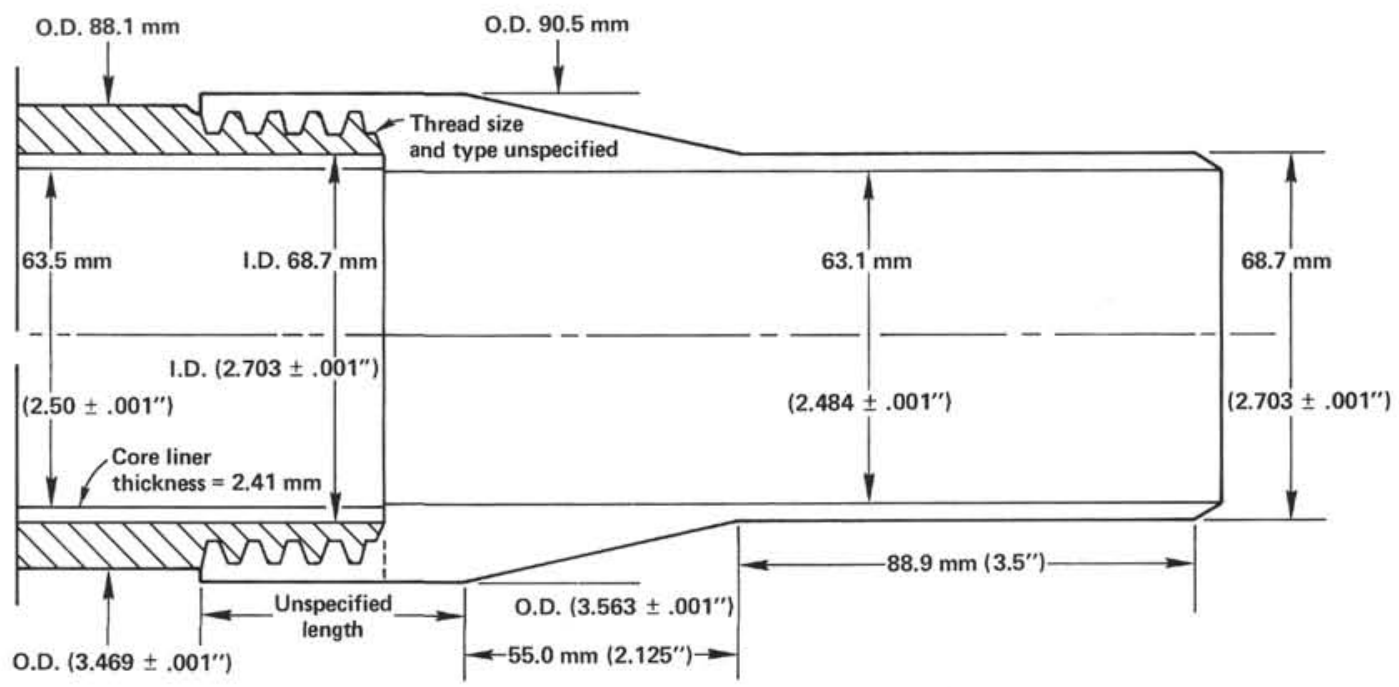

Figure 11. Modified HPC sampler head. O.D. = outside diameter; I.D. = inner diameter

The difference between the outside diameter of the sampler head $\left(D_{s}\right)$ and the outside diameter of the core barrel $\left(D_{c}\right)$ is termed the "outside clearance ratio" (Rosfelder and Marshall, 1967):

$$
C_{o}(\%)=100\left(D_{s}-D_{c}\right) / D_{c} .
$$

For cohesive sediments, the clearance ratio should be less than $3 \%$ for normal cutting edges.

The expanded head will substantially reduce sidewall friction between the sampler (core barrel) and the sediment column. To obtain longer sediment cores, it would be necessary to reduce the friction between the sediment and the core liner. This may be accomplished by reducing the inside diameter of the sampling head so that it is slightly smaller than the inside diameter of the core liner, $D_{i c}$. Accordingly, the degree of sampling disturbance would also be affected by the inside clearance ratio:

$$
C_{r}(\%)=100\left(D_{i c}^{2}-D_{i}^{2}\right) / D_{i}^{2} .
$$

If this ratio becomes too large, the sample may expand excessively as it passes into the core liner and its shear strength may be considerably reduced (Peck et al., 1974). For undisturbed samples of high quality, the inside clearance ratio should not exceed $1.5 \%$. For the modified HPC sampler head shown in Figure 11, the inside clearance ratio, $C_{r}$, equals $1.3 \%$; the outside clearance ratio, $C_{o}$, equals $2.7 \%$; and area ratio, $A_{r}$, equals $18.5 \%$. This modification falls within the limits defined earlier.

\section{CONCLUSIONS}

Sampling and testing have been done on cores obtained from a deep ocean basin using the HPC device. Two general types of sediment were encountered: a terrigenous clay and calcareous oozes. The measured properties for these sediments were consistent with previous data on sediments of these types. Expected engineering characteristics were documented by the testing program.
The HPC was used and was effective in taking highquality specimens of core. Certain characteristics of the coring device can and should be improved to reduce disturbance. The most important of these are: (1) increase individual core length, (2) reduce sample disturbance at the cutter head, (3) reduce friction between the core barrel and the sediment column, and (4) reduce friction between the core sample and the polycarbonate core liner. In addition to the disturbance associated with the HPC, some disturbance resulted from handling the cores and the release of hydrostatic head. It was impossible in this testing program to separate the effects of these three forms of disturbance. The overall improvement of sediment quality compared with other sampling techniques would indicate that the HPC has great potential for obtaining high-quality undisturbed samples.

In general, the terrigenous clays were less disturbed than the calcareous oozes.

\section{ACKNOWLEDGMENTS}

We are grateful to the National Science Foundation and JOIDES for the invitation to participate in the Deep Sea Drilling Project. The geotechnical testing necessary for this paper was performed by Scott A. Miller. This study was supported in part by Carnegie-Mellon University. Ed Clukey and James Booth are gratefully acknowledged for reviewing this paper.

\section{REFERENCES}

American Society for Testing and Materials, 1979. Annual Book of ASTM Standards, Soil and Rock; Building Stones; Peat, Pt. 19: Philadelphia, Pennsylvania.

Bennett, R. H., and Keller, G. H., 1973. "Physical properties evaluation. In van Andel, Tj. H., and Heath, G. R., et al., Init. Repts. $D S D P, 16$ : Washington (U.S. Govt. Printing Office), 521-528,

Boyce, R. E., 1974. Instructions for Grain Density, Wet-Bulk Density, Water Content, and Porosity Determinations by Individual Samples and Gamma Ray Attenuation Porosity Evaluator: La Jolla, California (Deep Sea Drilling Project, Scripps Institution of Oceanography).

Buchan, S., Dewes, F. C. D., McCann, D. M., and Taylor Smith, D., 1967. Measurements of the acoustic and geotechnical properties of marine sediment cores. Proc. Int. Res. Conf. Mar. Geotechnique, Monticello, Illinois, pp. 65-92. 
Casagrande, A., 1936. The determination of the pre-consolidation load and its practical significance. Proc. First Int. Conf. Soil Mech. Foundation Eng., Cambridge, Massachusetts, pp. 60-72.

Demars, K. R., and Nacci, V. A., 1978. Significance of Deep Sea Drilling Project sediment physical property data. Mar. Geotech. 3(2):151-170.

Hamilton, E. L., 1976. Variations of density and porosity with depth in deep-sea sediments. J. Sediment. Petrol., 46(2):280-300.

Lambe, T. W., 1951. Soil Testing for Engineers: New York (Wiley).

Peck, R. B., Hanson, W. E., and Thornburn, T. H., 1974. Foundation Engineering: New York (Wiley).

Rosfelder, A. M., and Marshall, N. F., 1967. Obtaining large, undisturbed, and oriented samples in deep water. Proc. Int. Res. Conf. Mar. Geotechnique, Monticello, Illinois, pp. 243-263.
Schmertman, J. M., 1955. The undisturbed consolidation of clay. Trans. Am. Soc. Civil Eng., 120:1201-1233.

Silva, A. J., 1974. Marine geomechanics: Overview and projections. In Inderbitzen, A. L. (Ed.), Deep-Sea Sediments: Physical and Mechanical Properties: New York (Plenum Press), pp. 45-76.

Storms, M. A., 1979. Hydraulic Piston Corer-Performance Summary: La Jolla, California (Deep Sea Drilling Project, Scripps Institution of Oceanography).

Terzaghi, K., and Peck, R. B., 1967. Soil Mechanics in Engineering Practice, (2nd ed.): New York (J. Wiley).

Date of Initial Receipt: August 10, 1982 